\title{
Evaluation of Perception, Attitude, and Impact of Club-house Noise Pollution on Mental Health of Individuals Living within Proximity of Club-houses in Abraka, Delta State, Nigeria
}

\section{${ }^{1}$ OMOGBIYA, AI; ${ }^{1 *}$ MOKE, EG; ${ }^{2}$ OJIEH, AE; ${ }^{3}$ ENAOHWO, MT; ${ }^{1}$ UMUKORO, EK; ${ }^{2}$ ANACHUNA, KK; ${ }^{1}$ OMILO, CU}

\author{
${ }^{1}$ Department of Pharmacology and Therapeutics, Delta State University, Abraka, Delta State, Nigeria. \\ ${ }^{2}$ Department of Physiology, Delta State University, Abraka, Delta State, Nigeria. \\ ${ }^{3}$ Department of Anatomy and Cell Biology, Delta State University, Abraka, Delta State, Nigeria. \\ *Corresponding Author Email: hiligoodies@gmail.com; Tel: +234-7061040692
}

\begin{abstract}
Noise pollution is becoming a major public health concern with all of its potential biological, social, physiological and psychological effects on the body. This study evaluated the perception, attitude, and impact of noise pollution from club houses on the mental health of individuals living within proximity of club houses in Abraka, Delta State, Nigeria. A cross-sectional descriptive study design was conducted among 400 randomly selected respondents who resided within proximity to nine different club houses. A well-structured questionnaire was used to collect data for the study and the data was presented as percentage using descriptive statistics. The respondents of this study (400) had a mean age of $25.06( \pm 0.62)$, most were students (78\%) and majority were single $(84.5 \%)$. Most respondents $(50.75 \%)$ reported that noise generated from these club houses were in forms of party noise $(50.75 \%)$ and loud music $(49.5 \%)$ occurring mostly at night. A larger proportion $(84 \%)$ of the respondents reported inability to cope with the noise, and $91.75 \%$ reported that their sleep was affected by noise. The noise resulted in depression in fewer respondents (33.5\%), although most respondents experienced nervousness (59.25\%), headache $(87.75 \%)$, fear $(71.5 \%)$, and were stressed $(75.25 \%)$ as a result of the noise. Sleep disorders, anxiety and depressive symptoms were more prevalent in people living in the vicinity of high noise generation than people who reside further away.
\end{abstract}

DOI: https://dx.doi.org/10.4314/jasem.v24i6.10

Copyright: Copyright (C) 2020 Omogbiya et al. This is an open access article distributed under the Creative Commons Attribution License (CCL), which permits unrestricted use, distribution, and reproduction in any medium, provided the original work is properly cited.

Dates: Received: 14 October 2019; Revised: 16 May 2020; Accepted: 10 June 2020

Keywords: Mental health, depression, aggressiveness, club house noise, proximity.

Noise pollution is a form of environmental noise with a damaging impact on the activity of human or animal life. The noise generated from machines, transport and transportation systems are major sources of outdoor noise worldwide (Fong, 2016). The main sources of noise in residential area are loud music and loud barking by domestic dogs, as well as loud talking or shouting by humans, although the latter is less persistent. Improper urban planning such as side-byside industrial and residential buildings can potentiate noise pollution in the residential areas. Noise pollution from household electricity generators is an evolving environmental degradation in many developing countries, generating noise level of about $97.60 \mathrm{~dB}$ (decibel) which far exceeds the WHO value of $50 \mathrm{~dB}$ allowed for residential areas (Wale et al., 2013). High noise levels can contribute to cardiovascular effects in humans and an increased incidence of coronary artery disease (Hoffman et al., 2006). While the elderly may suffer from cardiac problems due to noise, children also suffer from it and can suffer permanent damage for life. Children who live in noisy environments have been shown to have elevated blood pressures and elevated levels of stress-induced hormones (Basner $e t$ al., 2014). Noise poses a serious threat to a child's physical and psychological health, including learning and behavior (Perillo et al., 2017; Lim et al., 2018). Noise pollution can be damaging to psychological and physiological health. Hypertension, high stress levels, tinnitus, hearing loss, sleep disturbances, and other harmful effects such as anger, withdrawal, depression, and agitation. (Fuller et al., 2007). Primary sleep disturbances include difficulty falling asleep, frequent awakenings, and alterations in sleep stages and depth, particularly a reduction in rapid eye movement (REM) sleep (Basner et al., 2014). Lack of sleep and disrupted circadian rhythms cause dwindled alertness leading to possible accidents, injuries, and death (Firdaus and Ahmad, 2010). Noise in combination with pre-existing anger, provocation, or hostility may trigger aggressive behavior (Passchier-Vermeer and Passchier, 2000). There is a significant increase in annoyance with noise 
(Basner et al., 2014). Noise annoyance in itself can be regarded as an environmental health risk (WHO, 2011). Noise sensitivity can be thought of as a personality trait that is stable over time and maybe be related to neuroticism (an enduring tendency to experience negative emotional states and feelings like anxiety and depression) (Miedema and Vos, 2003; Schutte et al., 2007). These individuals are also more likely to be affected by environmental stress and interpret ordinary situations as threatening and tend to be hostile, self-conscious, insecure and vulnerable (Weiten, 2004). The detrimental effects of noise may help explain some of the dehumanization seen in the modern, congested, and noisy urban environment (Goines and Hagler, 2007). Various studies have investigated the effect of noise on performance and mental stability. However, there is the necessity of assessing noise generated from club houses and its effect on people residing nearby. This study was, therefore, aimed at evaluating the perception, attitude, and impact of noise pollution from club houses on the mental health of individuals living within proximity of club houses in Abraka, Delta State, Nigeria.

\section{MATERIALS AND METHODS}

A cross-sectional descriptive study design was used to evaluate the perception and attitude towards club house-mediated noise of residents within proximity of club houses in Abraka, Delta State. Nigeria. The survey was conducted in 2018 among 400 randomly selected respondents who resided within proximity to nine (9) different club houses; children and nonresidents of the community were excluded. Ethical approval was gotten from the 'Ethical Committee' of the Faculty of Basic Medical Sciences, Delta State University, Abraka, Nigeria. A well-structured questionnaire was used to collect data for the study from participants who gave informed oral consent. Information collected comprised the sociodemographic data, perception of, and attitude towards club house-mediated noise. Data was presented as percentage using descriptive statistics.

\section{RESULTS AND DISCUSSION}

The socio-demographic data of the study respondents is shown in Table 1. The respondents of this study (400) had a mean age of $25.06( \pm 0.62), 50 \%$ male and $50 \%$ female. Most of the respondents $(78 \%)$ were students, while few were either employed (8\%), selfemployed $(6.25 \%)$, or unemployed $(7.75 \%)$, with majority being single (84.5\%). Table 2 shows the perception of respondents and their attitude towards noise generation by club houses in Abraka metropolis. All respondents resided close to club houses and majority of them (62.25) reported that these club houses generated noise.

Table 1: Socio-demographic data

\begin{tabular}{lll}
\hline Variable & $\begin{array}{l}\text { Frequency } \\
(\mathbf{n}=\mathbf{4 0 0})\end{array}$ & $\begin{array}{l}\text { Percentage } \\
(\mathbf{\%})\end{array}$ \\
\hline Age & & \\
$18-21$ & 54 & 13.5 \\
$22-25$ & 190 & 47.5 \\
$26-29$ & 102 & 25.5 \\
$\geq 30$ & 54 & 13.5 \\
Mean age & $25.06 \pm 0.62$ & \\
Marital Status & & \\
Married & 62 & 15.5 \\
Single & 338 & 84.5 \\
Widowed & 0 & 0 \\
Gender & & \\
Male & 200 & 50 \\
Female & 200 & 50 \\
Occupation & & \\
Student & 312 & 78 \\
Civil servant & 32 & 8 \\
Self-employed & 25 & 6.25 \\
Unemployed & 31 & 7.75 \\
\hline
\end{tabular}

Most respondents (50.75\%) reported that noise generated from these club houses were in forms of party noise, $49.5 \%$ indicated reported that the noise was in form of loud music, while $19.5 \%$ reported that the noise was in form of shouts and fights. Majority of the respondents $(77 \%)$ also reported that the noise mostly occurred at night.

Table 2: Respondents' perception and attitude towards club house-

\begin{tabular}{|c|c|c|}
\hline Variable & $\begin{array}{l}\text { Frequency } \\
(\mathrm{n}=\mathbf{4 0 0 )}\end{array}$ & $\begin{array}{l}\text { Percentage } \\
(\%)\end{array}$ \\
\hline \multicolumn{3}{|c|}{$\begin{array}{l}\text { Do you live close to any } \\
\text { club houses in Abraka? }\end{array}$} \\
\hline Yes & 400 & 100 \\
\hline No & 0 & 0 \\
\hline \multicolumn{3}{|c|}{$\begin{array}{l}\text { In what form do these club } \\
\text { houses generate noise?* }\end{array}$} \\
\hline Loud music & 198 & 49.5 \\
\hline Shouts and fights & 78 & 19.5 \\
\hline Gunshots & 3 & 0.75 \\
\hline Party noises & 203 & 50.75 \\
\hline \multicolumn{3}{|c|}{$\begin{array}{l}\text { In what part of the day do } \\
\text { they generate noise the } \\
\text { most? }\end{array}$} \\
\hline Morning & 20 & 5.0 \\
\hline Afternoon & 8 & 2.0 \\
\hline Evening & 64 & 16.0 \\
\hline Night & 308 & 77.0 \\
\hline \multicolumn{3}{|c|}{$\begin{array}{l}\text { Are you able to cope with } \\
\text { noise? }\end{array}$} \\
\hline Yes & 61 & 15.25 \\
\hline No & 339 & 84.75 \\
\hline \multicolumn{3}{|c|}{$\begin{array}{l}\text { Do the noise affect your } \\
\text { quality of sleep? }\end{array}$} \\
\hline Yes & 367 & 91.75 \\
\hline No & 33 & 8.25 \\
\hline \multicolumn{3}{|c|}{$\begin{array}{l}\text { Do you get annoyed by } \\
\text { increased level of noise? }\end{array}$} \\
\hline Yes & 292 & 73.0 \\
\hline No & 108 & 29.0 \\
\hline
\end{tabular}


The attitude of respondents towards noise generation by club houses shows that a larger proportion (84\%) of the respondents are not able to cope with the noise, which is in contrast to $15.25 \%$ who could cope. Almost all the respondents $(91.75 \%)$ reported that their sleep was affected by noise and $73 \%$ reported that they become annoyed by increased levels of noise (Table 2). The effect of noise on mental health is depicted in Table 3. Loss of concentration was reported by $78 \%$ of the respondents while $61.75 \%$ reported that their working efficiency was affected during the period of the noise. The noise resulted in depression in fewer respondents (33.5\%), although most respondents experienced nervousness (59.25\%), headache $(87.75 \%)$, fear $(71.5 \%)$, and were stressed $(75.25 \%)$ as a result of the noise.

Table 3: Effect of noise on mental health

\begin{tabular}{|c|c|c|}
\hline Variable & $\begin{array}{l}\text { Frequency } \\
(n=400)\end{array}$ & $\begin{array}{l}\text { Percentage } \\
(\%)\end{array}$ \\
\hline 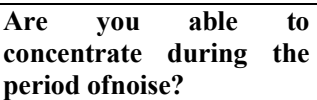 & & \\
\hline Yes & 88 & 22.0 \\
\hline No & 312 & 78.0 \\
\hline \multicolumn{3}{|l|}{$\begin{array}{l}\text { Do the noise affect your } \\
\text { working efficiency? }\end{array}$} \\
\hline Yes & 247 & 61.75 \\
\hline No & 153 & 38.25 \\
\hline \multicolumn{3}{|l|}{$\begin{array}{l}\text { Do the noise make you } \\
\text { depressed? }\end{array}$} \\
\hline Yes & 134 & 33.5 \\
\hline No & 266 & 66.5 \\
\hline \multicolumn{3}{|l|}{$\begin{array}{l}\text { Do you get nervous or } \\
\text { agitated during period of } \\
\text { noise? }\end{array}$} \\
\hline Yes & 237 & 59.25 \\
\hline No & 163 & 40.75 \\
\hline $\begin{array}{l}\text { Do the noise cause } \\
\text { headache? }\end{array}$ & & \\
\hline Yes & 351 & 87.75 \\
\hline No & 49 & 12.25 \\
\hline \multicolumn{3}{|l|}{$\begin{array}{l}\text { Do you experience fear } \\
\text { from noise? }\end{array}$} \\
\hline Yes & 286 & 71.5 \\
\hline No & 114 & 28.5 \\
\hline \multicolumn{3}{|l|}{$\begin{array}{l}\text { Are you stressed in any } \\
\text { way due to noise? }\end{array}$} \\
\hline Yes & 301 & 75.25 \\
\hline No & 99 & 24.75 \\
\hline
\end{tabular}

This was a cross-sectional study that examined the perception, attitude, and impact of noise pollution from club houses on the mental health of individuals living within proximity of club houses in Abraka, Delta State, Nigeria. The present study revealed that club house-mediated noise has negative effects on the performance and mental health of people who resided near club houses. In this study, the mean age of respondents was $25.06 \pm 0.06$ years and most were students. The large proportion of young men in Abraka is possibly because of the presence of a tertiary institution in the community, and the fact that youths may prefer to reside at areas that are proximate to social event centres perhaps due to their nightlife habits (Santani et al., 2016). The study shows that the noise from club houses was at night and they were generated from the club houses in the form of loud music or party noises. Most of the respondents in this study stay close to this club houses and they confirmed that noises are generated from these club houses. It is not surprising that most of the respondents are not able to cope with noise and are made annoyed by the noise generation. This is in agreement with studies conducted in Sweden by Berglund and Nilsson (2006), which concluded that noise negatively impact the quality of life of residents following assessment of how adverse health effects of noise are related to individual exposure and perceived soundscapes in residential areas with and without access to quiet areas. Likewise, Klæboe (2007) reported that increase in residential noise annoyance was a resultant effect from noisy neighborhoods primarily exposed to low residential noise levels whereas a reduced residential noise annoyance was seen in quiet neighborhood areas primarily at intermediate and high residential noise levels. The present study also indicated that club house-mediated noise affects the concentration and working efficiency of individuals, thus resulting in loss of attentiveness and low competence at execution of given tasks. This study revealed the harmful impact of club house-mediated noise on mental health as most respondents experienced nervousness, headaches, and fear, and they were also stressed as a result of such noise. This finding is consistent with studies by Beutel et al., (2016) which reported that much noise annoyance was associated with a two-fold higher occurrence of depression and anxiety. Also, findings have shown that high noise annoyance is associated with impairment in mental health, and that this association may be variant with the source of environmental noise (Hammersen et al., 2016; Jensen et al., 2019). Lim et al., (2018) stated that noise is an expected problem in modern societies, and that sensitivity to noise and noise itself play a vital function in children and adolescent mental health status. Welldocumented studies have shown that noise exposure contributes to hearing loss, tinnitus, heart disease, stroke, anxiety, stress, depression, learning difficulties, job performance, sleep disorders, and reduced cognitive capabilities (Münzel et al., 2014; Basner et al., 2015; Tzivian et al., 2015). A similar survey in Egypt revealed same deleterious effects of hearing impairment, raised blood pressure, headaches, disturbed sleep, and symptoms of anxiety to be so prominent among airport workers exposed to noise than the controls (Rizk et al., 2016) 
Conclusion: Noise pollution is a chief public health burden as it affects the human health in both biological, social, physiological and psychological aspects. This study revealed negative mental health impacts such as sleep disorders, anxiety and depressive symptoms of club house-mediated noise on residents within proximity to club houses.

\section{REFERENCES}

Basner, M; Babisch, W; Davis, A; Brink, M; Clark, C; Janssen, S; Stansfeld, S (2014). Auditory and nonauditory effects of noise on health. Lancet. 383(9925): 1325-1332.

Basner, M; Brink, M; Bristow, A; de Kluizenaar, Y; Finegold, L; Hong, J; Janssen, SA; Klaeboe, R; Leroux, T; Liebl, A; Matsui, T; Schwela, D; Sliwinska-Kowalska, M; Sörqvist, P (2015). ICBEN review of research on the biological effects of noise 2011-2014. Noise Health. 17(75): 57-82.

Berglund, B; Nilsson, M (2006). On a Tool for Measuring Soundscape Quality in Urban Residential Areas. Acta. Acust. united Ac. 92: 938-944.

Beutel, ME; Jünger, C; Klein, EM; Wild, P; Lackner, K; Blettner, M; Binder, H; Michal, M; Wiltink, J; Brähler, E; Münzel, T (2016). Noise Annoyance Is Associated with Depression and Anxiety in the General Population- The Contribution of Aircraft Noise. PLoS One. 11(5): e0155357.

Firdaus, G; Ahmad, A (2010). Noise Pollution and Human Health: A Case Study of Municipal Corporation of Delhi. Indoor Built Environ. 19: $648-656$.

Fong, J (2016). Making Operative Concepts from Murray Schafer's Soundscapes Typology: A Qualitative and Comparative Analysis of Noise Pollution in Bangkok, Thailand and Los Angeles, California. Urban Stud. 53(1): 173-192

Fuller, RA; Warren, PH; Gaston, KJ (2007). Daytime noise predicts nocturnal singing in urban robins. Biol. Lett. 3(4): 368-70.

Goines, L; Hagler, L (2007). Noise Pollution: A Modern Plague. South. Med. J. 100(3): 287-294

Hammersen, F; Niemann, H; Hoebel, J (2016). Environmental Noise Annoyance and Mental Health in Adults: Findings from the Cross-
Sectional German Health Update (GEDA) Study 2012. Int. J. Environ. Res. Public Health. 13: 954.

Hoffmann, B; Moebus, S; Stang, A; Beck, E; Dragano, N; Möhlenkamp, S; Schmermund, A; Memmesheimer, M; Mann, K; Erbel, R; Jöckel, K on behalf of the Heinz Nixdorf RECALL Study Investigative Group (2006). Residence close to high traffic and prevalence of coronary heart disease. Eur. Heart J. 27(22): 2696-2702.

Jensen, HA; Rasmussen, B; Ekholm, O (2019). Neighbour noise annoyance is associated with various mental and physical health symptoms: results from a nationwide study among individuals living in multi-storey housing. $B M C$ Public Health. 19: 1508.

Klæboe, R (2007). Are adverse impacts of neighbourhood noisy areas the flip side of quiet area benefits? Appl. Acoust. 68: 557-575.

Lim, J; Kweon, K; Kim, HW; Cho, SW; Park, J; Sim, CS (2018). Negative impact of noise and noise sensitivity on mental health in childhood. Noise Health. 20(96): 199-211.

Miedema, HM; Vos, H (2003). Noise sensitivity and reactions to noise and other environmental conditions. J. Acoust. Soc. Am. 113(3): 14921504.

Münzel, T; Gori, T; Babisch, W; Basner, M (2014). Cardiovascular effects of environmental noise exposure. Eur. Heart J. 35(13): 829-836.

Passchier-Vermeer, W; Passchier, WF (2000). Noise exposure and public health. Environ. Health Perspect. 108(Suppl 1): 123-131.

Perillo, A; Mazzoni, LG; Passos, LF; Goulart, VDL; Duca, C; Young, RJ (2017). Anthropogenic noise reduces bird species richness and diversity in urban parks. Ibis. 159(3): 638-646.

Rizk, SA; Sharaf, NA; Mahdy-Abdallah, H; ElGelil, KS (2016). Some health effects of aircraft noise with special reference to shift work. Toxicol. Ind. Health. 32(6): 961-967

Santani, D; Biel, J; Labhart, F; Truong, J; Landolt, S, Kuntsche, E; Gatica-Perez, D (2016). The Night is Young: Urban Crowdsourcing of Nightlife Patterns. Proc. ACM UbiComp. p. 427-438 
Schutte, M; Marks, A; Wenning, E; Griefahn, B (2007). The development of the noise sensitivity questionnaire. Noise Health. 9(34): 15-24.

Tzivian, L; Winkler, A; Dlugaj, M; Schikowski, T; Vossoughi, M; Fuks, K; Weinmayr, G; Hoffmann, B (2015). Effect of long-term outdoor air pollution and noise on cognitive and psychological functions in adults. Int. J. Hyg. Environ. Health. 218(1): 1-11

Wale, MA; Simpson, SD; Radford, AN (2013). Sizedependent physiological responses of shore crabs to single and repeated playback of ship noise. Biol. Lett. 9(2): 20121194

Weiten, W (2004). Psychology: Themes and Variations. Sixth edition, Belmont: Thomson Learning, Inc.

World Health Organization (2011). Burden of Disease from Environmental Noise. Quantification of Healthy Life Years Lost in Europe. World Health Organization; Copenhagen, Denmark. 